\title{
Miranda
}

Revue pluridisciplinaire du monde anglophone /

Multidisciplinary peer-reviewed journal on the English-

speaking world

$17 \mid 2018$

Paysages et héritages de David Bowie

\section{Defanging the Vampire : The Crushing Gaze of Metadiegesis in Shadow of the Vampire (E. Elias Merhige, 2000)}

Julian Caradec

\section{OpenEdition}

\section{Journals}

Electronic version

URL: http://journals.openedition.org/miranda/13601

DOI: 10.4000/miranda.13601

ISSN: 2108-6559

\section{Publisher}

Université Toulouse - Jean Jaurès

\section{Electronic reference}

Julian Caradec, "Defanging the Vampire: The Crushing Gaze of Metadiegesis in Shadow of the Vampire (E. Elias Merhige, 2000)", Miranda [Online], 17 | 2018, Online since 28 September 2018, connection on 16 February 2021. URL: http://journals.openedition.org/miranda/13601 ; DOI: https://doi.org/10.4000/ miranda.13601

This text was automatically generated on 16 February 2021.

\section{cc)}

Miranda is licensed under a Creative Commons Attribution-NonCommercial-NoDerivatives 4.0

International License. 


\title{
Defanging the Vampire : The Crushing Gaze of Metadiegesis in Shadow of the Vampire (E. Elias Merhige, 2000)
}

\author{
Julian Caradec
}

1 In the fourth act of F.W Murnau's Nosferatu (1922), the titular vampire Count Orlock (Max Schreck) arrives from Transylvania in the fictional town of Wisborg. There, he can be seen lurking the streets, carrying his coffin, as a blue gelatin filter signals night. However, as in every exterior scene in the film, Max Schreck is shot in broad daylight, as a type of film stock sensitive enough to allow shooting anything less than brightly lit spaces had yet to be invented in 1922. This melancholy image of the oblivious vampire in broad daylight is an apt synecdoche for the impetus behind E. Elias Merhige's 2000 metafilm ${ }^{1}$ Shadow of the Vampire, an exercise in alternate reality depicting a tyrannical F.W Murnau (John Malkovich) casting an actual vampire ${ }^{2}$ (Willem Dafoe) as the lead role of his expressionist masterpiece Nosferatu. Merhige's film is a simple and, at first glance, amusing exercise in a story based on the origins of the film, apparently meant to lend a rightly earned justification for the haunting and enduring figure of Count Orlock, a primordial monster of the cinematic horror canon. However, along the way, the film unpacks an extensive field of metafictional devices and discourses. By juxtaposing its apocryphal plot and making its diegesis and that of its fictional recreation of Nosferatu interplay, Shadow of the Vampire unfolds deep perspectives about history, representation, metafiction and art.

2 According to Marc Cerisuello, a metafilm sheds critical light on cinema by being explicitly about it at a given moment in time. Shadow of the Vampire has a lot to say about horror, although perhaps not as frontally as it may seem. Indeed, if Merhige's film presents itself as a horror film, this is only incidental to its subject matter. At the heart of Shadow of The Vampire are the ironic dissonances which emerge when monsters are plucked from the past and asked to perform for modern, film-savvy audiences, thus 
opening up questions about the origins and evolution of horror and cinema in general. For Linda Hutcheon, "[p] ostmodern fiction suggests that to re-write or to re-present the past in fiction and in history is, in both cases, to open it up to the present, to prevent it from being conclusive and teleological." (Hutcheon, 1988, p. 110) These dissonances are not victimless. If the sparse murders of this postmodernist metafilm are almost treated as an afterthought of obligatory decorum, the true exactions depicted in Shadow of The Vampire are that of a metafictional text tearing its subject apart. The "vampire playing an actor playing a vampire" is splintered between different diegeses, none of which acknowledge him as master of his own nature. This slow and agonizing process unfolds under the overpowering gaze of Murnau, who slowly reveals himself as the film's true villain. The transition depicted in the film from real-life vampire to celluloid monster implicitly and explicitly represents a loss of status. In a dialogue scene between the vampire and the crew, the creature expresses the sadness he experienced reading Bram Stoker's Dracula. In the novel, the aristocratic vampire lives in his castle alone, with no servants: "The loneliest part of the book comes when the man accidentally sees Dracula setting his table" [51:39]. This transition from creature to character echoes Walter Benjamin's theory of "The Work of Art in the Age of Mechanical Reproduction," with the vampire as a stand-in for the old modes of pictorial representations. According to Benjamin, a work of art is a unique piece, every other version of it being either a copy or a forgery. The consequence of this is a ritual dimension to the work of art, meaning that its use value and subsequently, its meaning is the unique privilege of the ruling class : "An ancient statue of Venus, for example, stood in a different traditional context with the Greeks, who made it an object of veneration, than with the clerics of the Middle Ages, who viewed it as an ominous idol." (Benjamin, 6) Benjamin saw the arrival of photography and film as a means of doing away with the ritual and the concept of the "original." Save for a few fetishistic collectors, there is no ritual aura to the original print of a film. Therefore, for a vampire to accept becoming a film character is to abandon his aristocratic status, it is accepting to become reproducible and relinquishing his privilege to uniqueness. The transition evokes bourgeois fears about art reaching the masses through technological progress. The displacement and duplication of representation is what Benjamin called the loss of aura. Although the vampire does not seem to acknowledge or lament the process he is a part of, glimpses of lucidity appear to reach him at times if only to be quickly forgotten for more immediate appetites. This article will thus tackle the formal and textual reflexive devices deployed in Shadow of the Vampire and make the case of their use toward a field of ethical metafiction by isolating what should be regarded as an interstitial third text in the film situated between the film's diegesis and Nosferatu's, in other words the film-being-filmed. Attention will be paid to the figure of the vampire and his navigation of this interstitial territory, which opens in a burst of uncanny terror only slowly to devolve into camp territory, as outlined by Susan Sontag. Finally, a look at the director-as-villain will unpack the subjectivity of the vampiric camera and its creation of a moral sphere under the guise of realism.

3 Shadow of the Vampire explicitly displays two primary texts : its own and Nosferatu's. The film creates composite scenes by inserting shots from Murnau's original film and recreating those featuring the vampire verbatim so as not to break its continuity (fig.1, $2,3)$. 
Figure 1

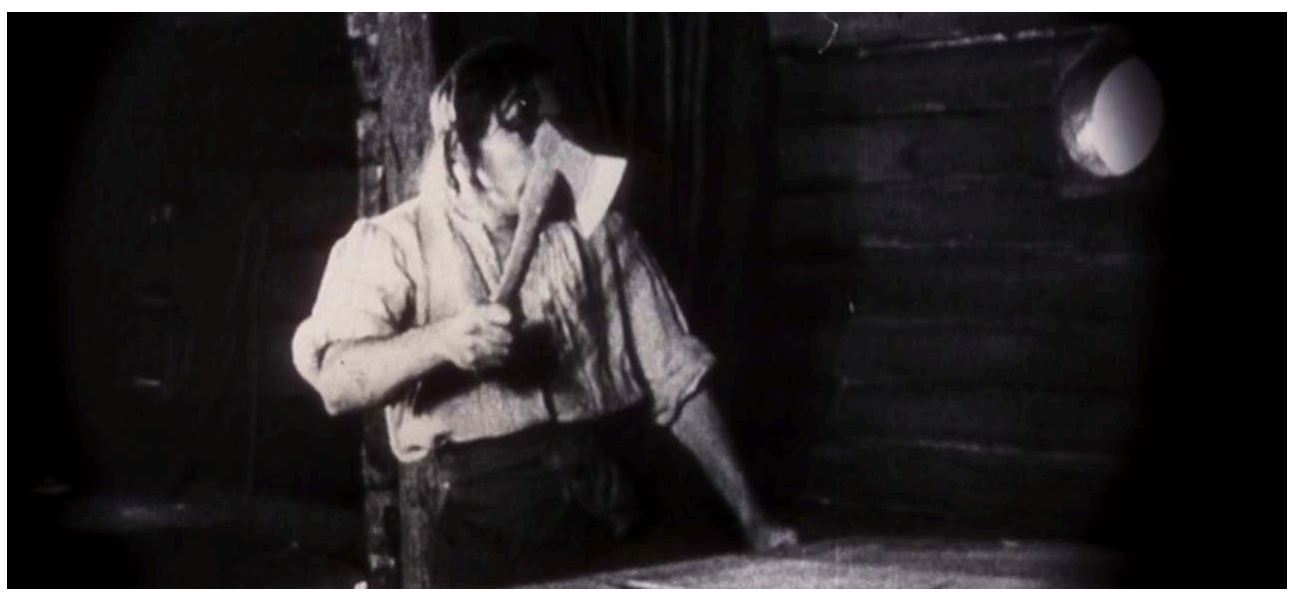

59 :25-Shot borrowed from Nosferatu

Figure 2

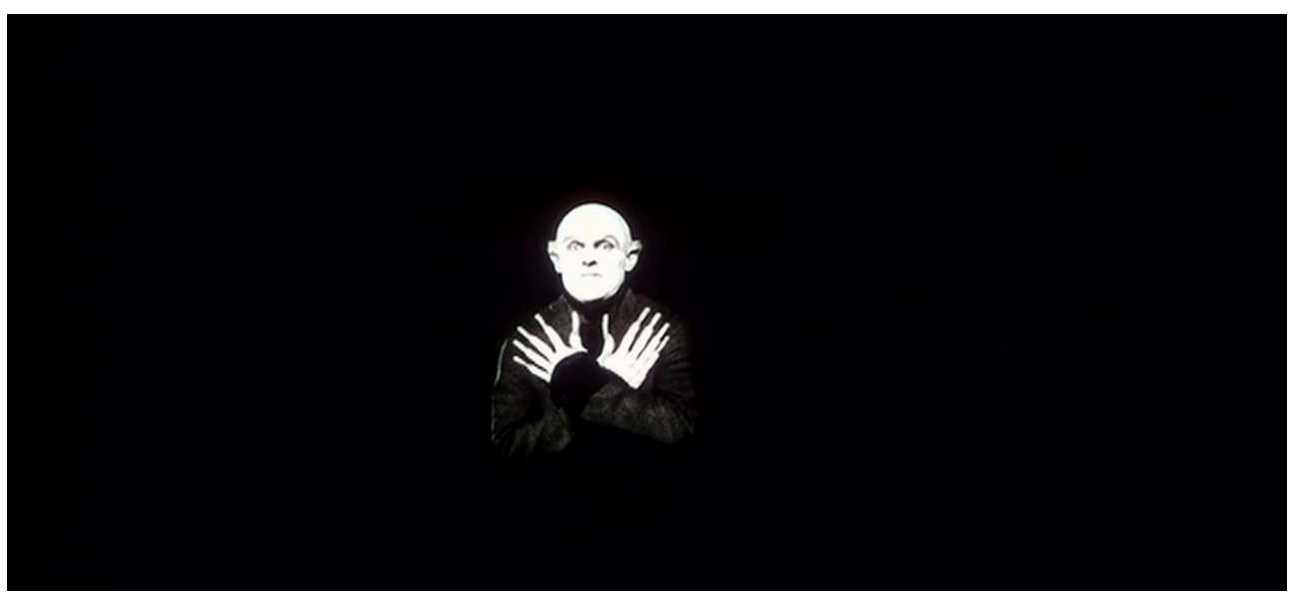

59 :32-Counter-shot recreated

Figure 3

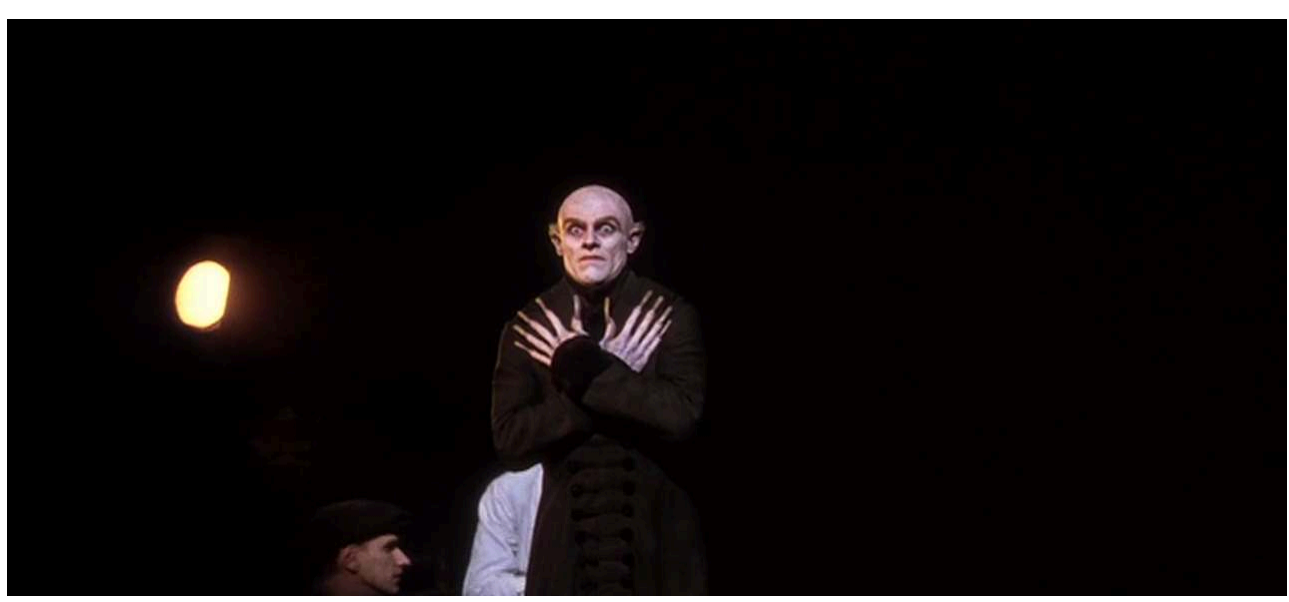

$59: 40$ - "And ... end !" Fade to color and primary diegesis 
4 As the explicit predicate of Merhige's film is to explore the origins of Murnau's, there is a juxtaposition of the two. This is made very clear from the opening shots of the film (fig.4, 5) where the eye of the director and the eye of the camera are successively shown in extreme close-ups, asserting the subjective power of both, but also establishing the dual texts and diegeses in the film: the eye of the director is intradiegetic, while suggesting the interplay between the different diegeses depicted in the film.

Figure 4

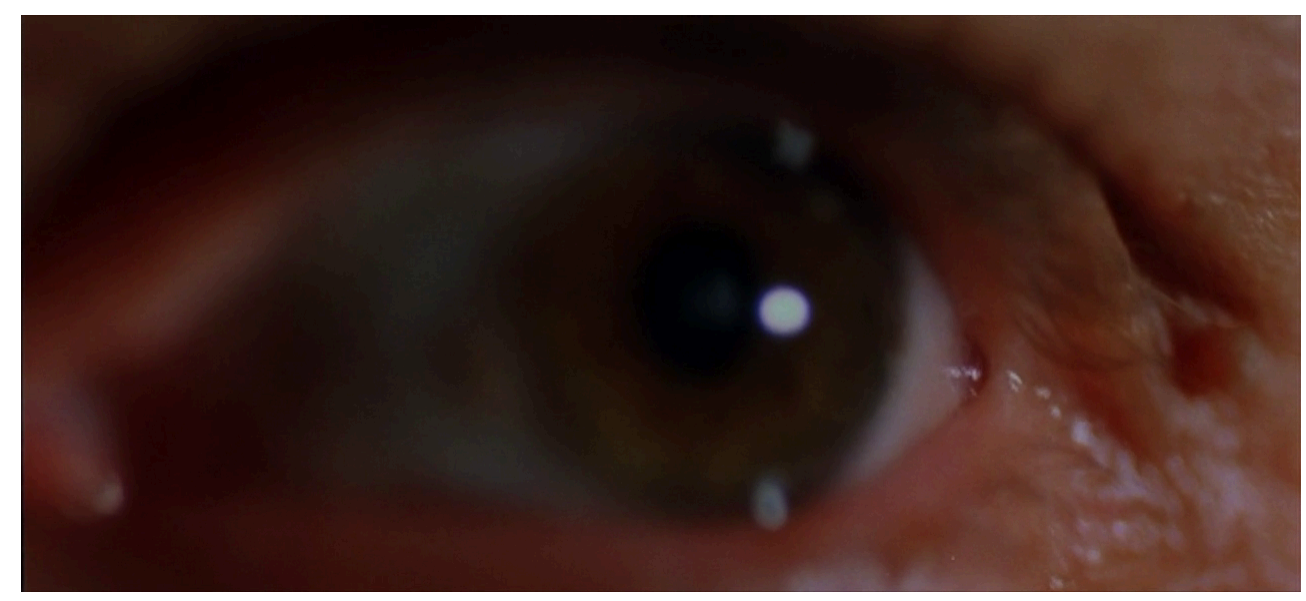

$06: 37-$ Opening shot. Extreme close-up. Focusing on Murnau's eye

Figure 5

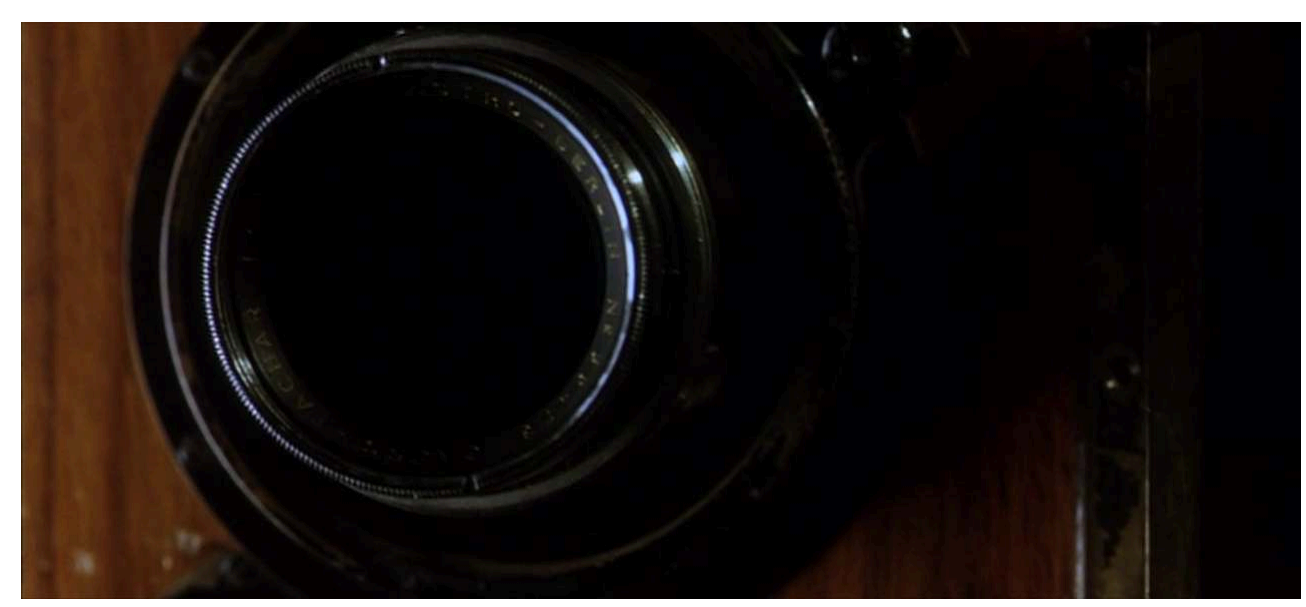

06 :39-Follow-up shot. Extreme close-up of Murnau's camera lens

5 Indeed, I would posit here that, between the primary text of the film and the lingering secondary text of Nosferatu, a third text can be observed in Shadow of The Vampire, due to the nature of film direction as depicted in the film, the visual transitions employed as well as the superimposition of images from Nosferatu*3 with the diegetic soundtrack of Shadow of The Vampire. This metadiegetic space composed of recreated Nosferatu images superimposed over the primary diegetic soundtrack is introduced by Murnau's lens (fig.5) and will run and evolve throughout the film. This is made clear by the very deliberate transitions the film operates every time a scene is about to be shot. In fig.6, the shot is aligned with the POV of Murnau's camera. After he declares "Roll camera," 
the color grading transitions into a high-contrast black and white, convincingly reproducing the look and feel of the $35 \mathrm{~mm}$ from 1922. Murnau calls "iris in," and the camera abides.

Figure 6

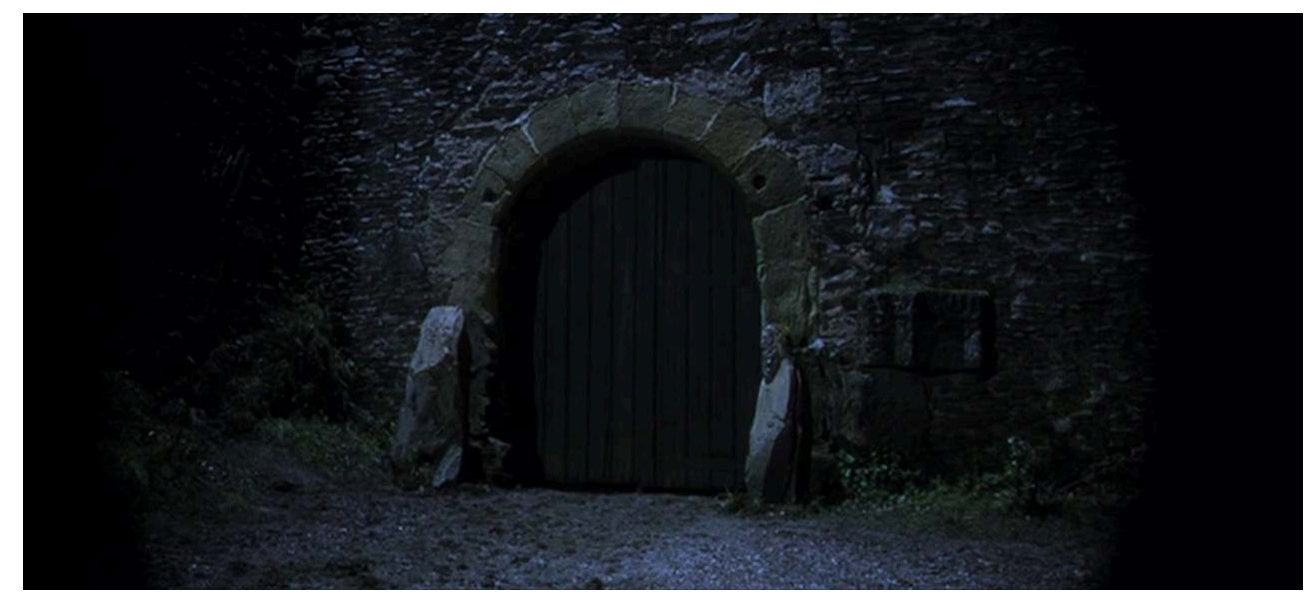

$21: 38$ - "Roll camera"

6 This phrase marks the moment when the metadiegetic text begins. The footage of Murnau's camera is his subjective vision, which is reinforced by his method of directing wherein, much like a stage director during rehearsals, he gives the instructions to his actors in real time, unimpaired by the presence of sound equipment. Murnau is here creating a film, not only for the audience of Nosferatu* but also for his actor. The improvisational quality of the direction is here aimed at befuddling Gustav (Eddie Izzard), the actor playing Hutter, to get a genuine expression from him. Here, Gustav is the actor/spectator of Murnau's unfolding film, an illustration of what Linda Hutcheon described as the postmodern reader of metafiction :

In all fiction, language is representational, but of a fictional "other" world, a complete and coherent "heterocosm" created by the fictive referents of the signs. In metafiction, however, this fact is made explicit and, while he reads, the reader lives in a world which he is forced to acknowledge as fictional. However, paradoxically the text also demands that he participate, that he engage himself intellectually, imaginatively, and affectively in its co-creation. This two-way pull is the paradox of the reader. (Hutcheon, 1980, p. 7)

The metadiegetic space created is hybrid and open-ended (fig.7). It claims a teleological dimension in that it recreates an object at the origin of the film, while maintaining a tension and uncertainty due to the directing style of Murnau, who can be heard offscreen-the diegetic soundtrack being unbroken and consistent with the reverse shots depicting the director in the primary diegesis's style. It is important to note, however, that the shots displaying the style of Nosferatu do not always aim at being verbatim recreations of the original. In the same scene, when we cut back to Gustav (fig. 8), a push-in is utilized, the iris effect has disappeared, and the camera slightly tracks in (which is, of course, as anachronistic as a night shooting, as well as confirmed by the reverse shot which shows the camera has not moved). 
Figure 7

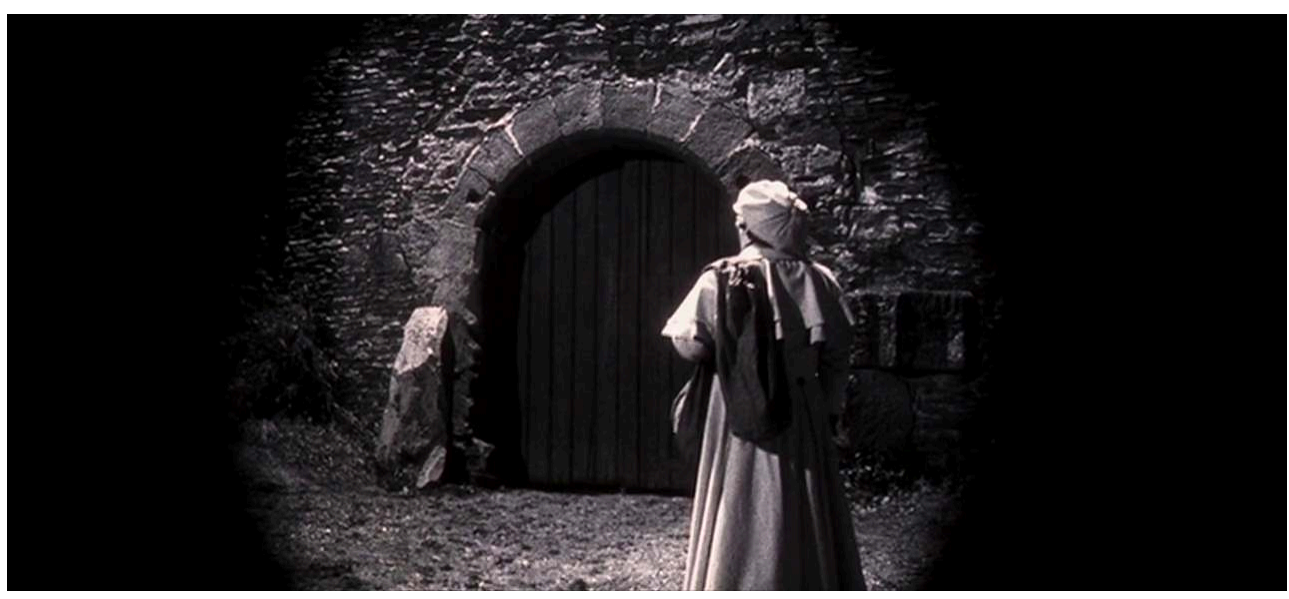

$21: 41-$-"ris in"

Figure 8

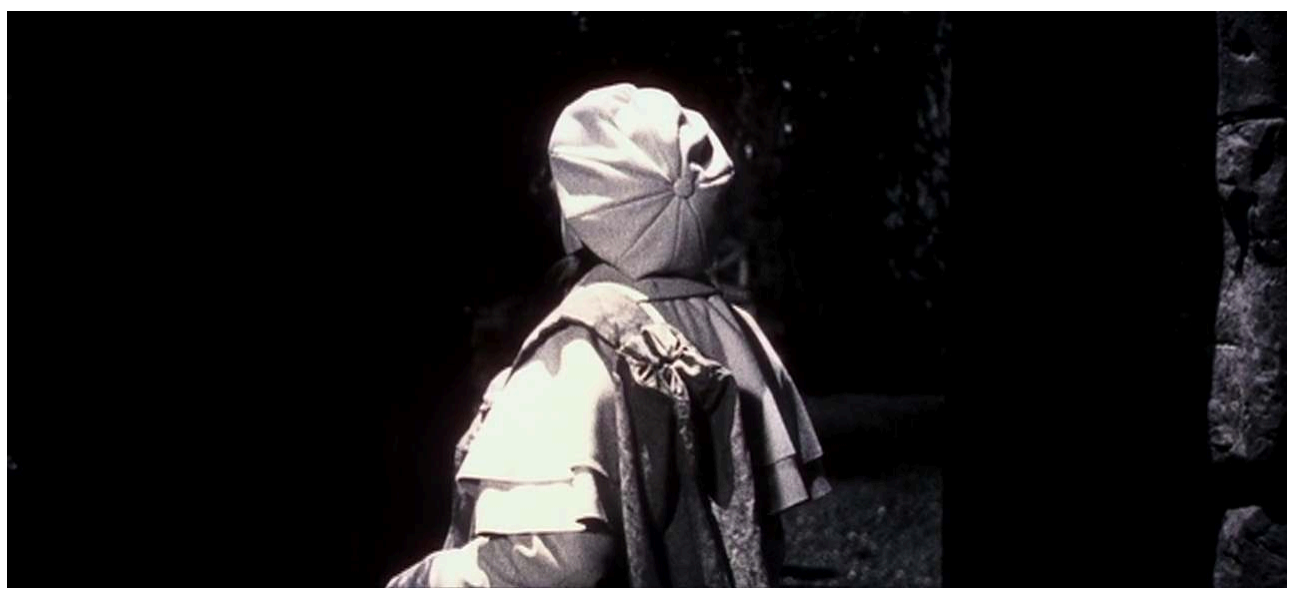

22 :13-The metadiegetic style of Nosferatu* extends outside of its boundaries

8 This means that the grainy black-and-white of the metadiegetic space has extended its influence to the primary diegesis, marking a shift in subjectivity. The shot is close to the subject, who is starkly lit from the back and surrounded by negative space, a rather traditional horror composition evoking isolation and fear. At this point, Gustav is an actor, a character and a spectator at the same time, living under the apprehension of his first meeting with the vampire. Murnau asks of his actor to take part in the creation of a fiction film, while being subjected to it at the same time. He will later apply the same method to the rest of the cast and crew. The way he positions Gustav as a spectator recalls Jacques Rancière's words about the modernist theater spectator :

We acknowledge these two paradigmatic attitudes epitomized by Brecht's epic theater and Artaud's theater of cruelty. On the one hand, the spectator must become more distant, on the other he must lose any distance [...] The project of reforming the theater ceaselessly wavered between these two poles of distant inquiry and vital embodiment. (Rancière, 275)

9 The metadiegetic space is the realm of Murnau's subjective power and the vampire is the figure that disrupts this space. While shooting the dinner scene, Murnau gives instructions to the vampire : "All right, Orlock, very good. You are reading your papers. 
Read your papers very intensely. After all, how often is it that you get correspondence from the living ?" [30:51-31:02]. This sentence gives the vampire pause and makes him break continuity by looking offscreen at the director (fig.9), thereby suggesting that the question could be received by the vampire and by "Orlock" simultaneously. By using the equivalent of free indirect speech, the director's invasiveness exposes the structural weakness of the barrier between both diegeses; he shows a vampire that neither knows nor adheres to the discourse and practice of filmmaking. In other words, the vampire can act his own part, but the fiction is broken as soon as the director tries to exert direct control over the character as he would with a regular actor.

Figure 9

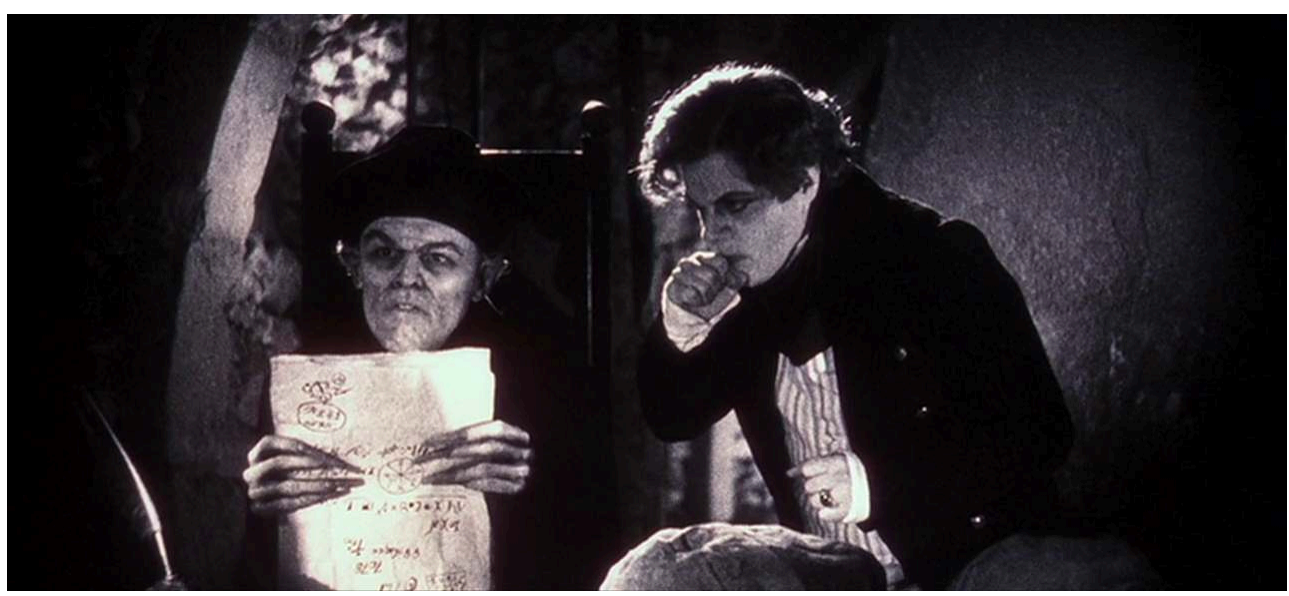

31 :03 - "No, don't look up !", the vampire disrupts the metadiegetic space

One of the murder scenes attempts to bridge the gap between vampire and diegesis through its aesthetics. Seemingly as an afterthought, the vampire kills a crew member on the fake boat constructed on set. If the scene is shot in the style of the primary diegesis, its composition clearly replicates a German expressionist style. The stark lighting, high contrast and use of negative space are reminiscent of Nosferatu and Caligari (Robert Wiene, 1920). However, depicted in a modern style, the scene feels anachronistic, not designed to inspire terror. The exaggerated poses of the vampire are purposefully out of place and out of time (fig.10). The expressionistic aesthetics also creates an aural discrepancy. Exaggerated motion and dramatic expressions were used in silent films to make up for the lack of information caused by the absence of sound. To quote Barbara Laner, in silent cinema, "visualization of sound is either realized by a conventionalized visual language that makes the spectator associate the visible images they see with certain sounds." (Laner, 35) By replicating the silent film aesthetic while keeping the diegetic soundtrack, the action becomes redundant. The vampire displays an outdated behavior in a modern diegesis which the film acknowledges in a comedic moment when his tiptoeing is heard by the crew member. 
Figure 10

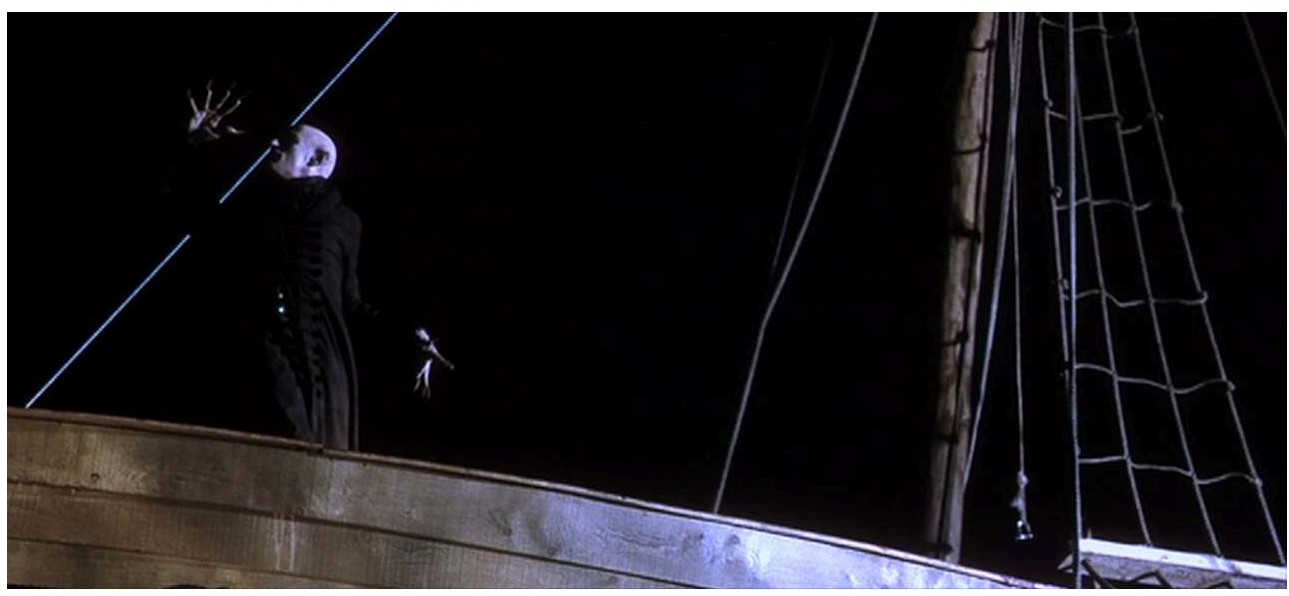

54 :22-Real murder on a fake boat

11 The primary text of Shadow of the Vampire can be read as a quest for identity. Near the beginning of the film, as the crew is on a train to Wismar, Murnau's figure is faded into the picture, delivering a grandiose speech about the imminent supremacy of cinema over art at large. The imagery is striking, woven into an interwar national narrative of artistic resurgence and self-reflection. The scene quotes several fundamental forces behind the early development of cinema such as L'arrivée du train en gare de La Ciotat (1896) and the Agit-Train (1921) of Alexander Medvedkin and Dziga Vertov. The train is shot at a sharp Dutch angle, as a statement of aesthetic and historical lineage (fig.11). A powerful industrial sense of surging into the future emerges as the context of Shadow of The Vampire.

Figure 11

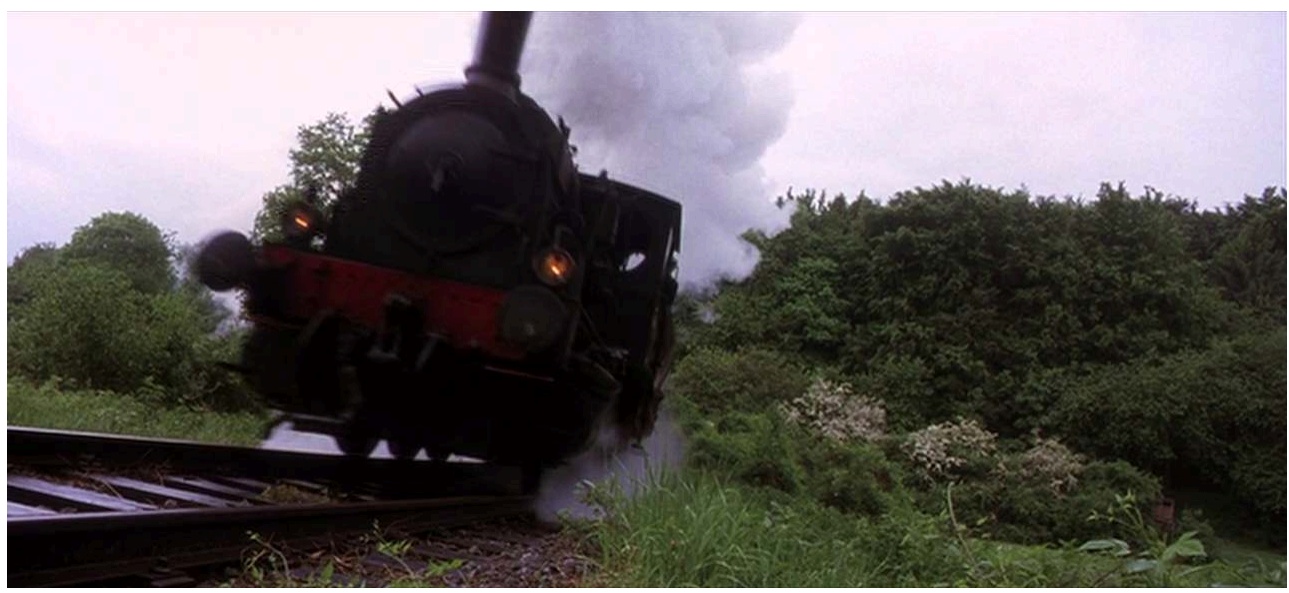

$14: 31-$ Film and industry

12 It is this movement in which the vampire must strive to find his place, though he will ultimately fail to do so. Indeed, the vampire, as we have seen, inhabits a liminal space between life and art, self-consciousness and obliviousness. He is the demonstration of what René Wellek called the ontological gap :

The recognition of the difference between life and art, of the "ontological gap" between a product of the mind, a linguistic structure, and the events in "real" life 
which it reflects, does not and cannot mean that the work of art is a mere empty

play of forms, cut off from reality. (Wellek, quoted in Hutcheon, 1980, p. 17.)

Several instances in the film translate the vampire's search for his place in this new world of projected shadows. Attempting to blend into his role as an actor, he asks Murnau for make-up, which the director refuses (30:23) barring him from the tools and devices of the film set. Lionel Abel argues that the self-conscious character in metatheatre is a Western tradition which hasn't waited for postmodernism to affirm itself : "The Western playwright is unable to believe in the reality of a character who is lacking in self-consciousness. Lack of self-consciousness is as characteristic of Antigone, Oedipus, and Orestes, as self-consciousness is characteristic of Hamlet, that towering figure of Western metatheatre" (Lionel Abel, quoted in Sontag, p. 133). The character of the vampire is particularly relevant, however, in that it has no interest in playing the role this tradition of self-consciousness demands. Whereas Hamlet struggled with his role to achieve his goals, the vampire is reluctant and disinterested. His attempts at taking part in cinema are half-hearted at best; he only wishes to perform his true, archaic, and soon to be extinct nature. The crux of this pull between role and self is epitomized quite explicitly in the projector scene when the vampire, cranking the projector containing the dailies on the wall, plays with the shadow of his hand (fig.12) and finally looks into the light source, projecting the image onto his own face (fig.13). In this scene, the vampire is quite literally superimposing the two diegeses in which he exists, tragically exposing his impossibility to reside in either as he is dying in one, and a lie in the other.

Figure 12

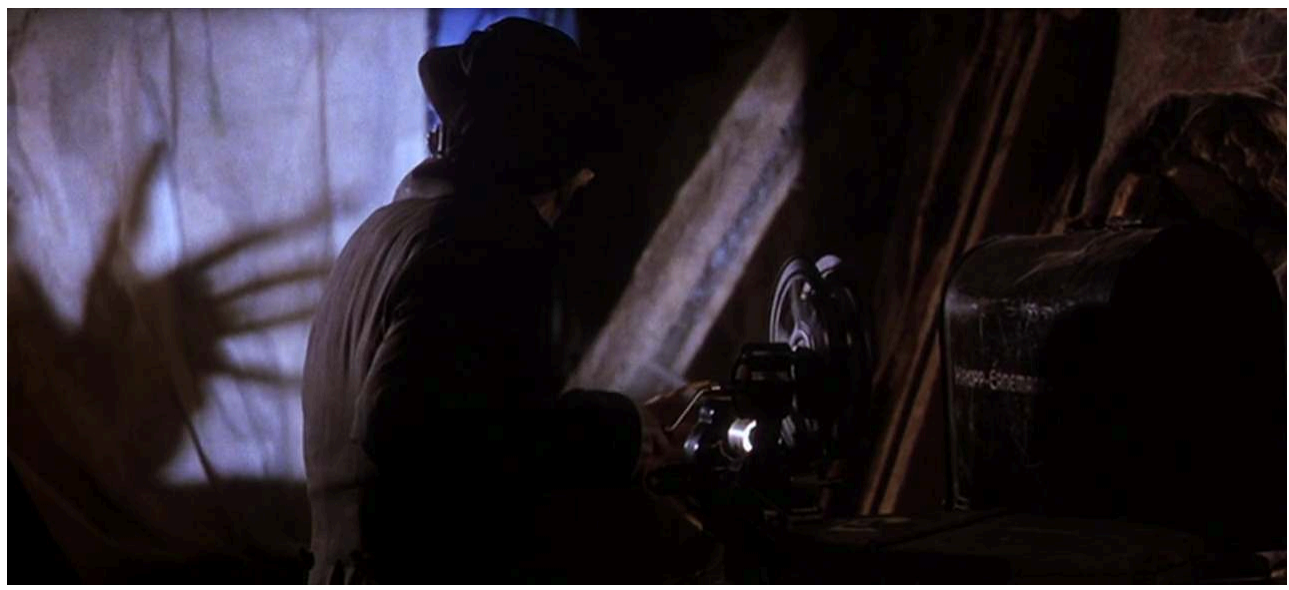

$40: 46-$ Trans-diegetic shadows 
Figure 13

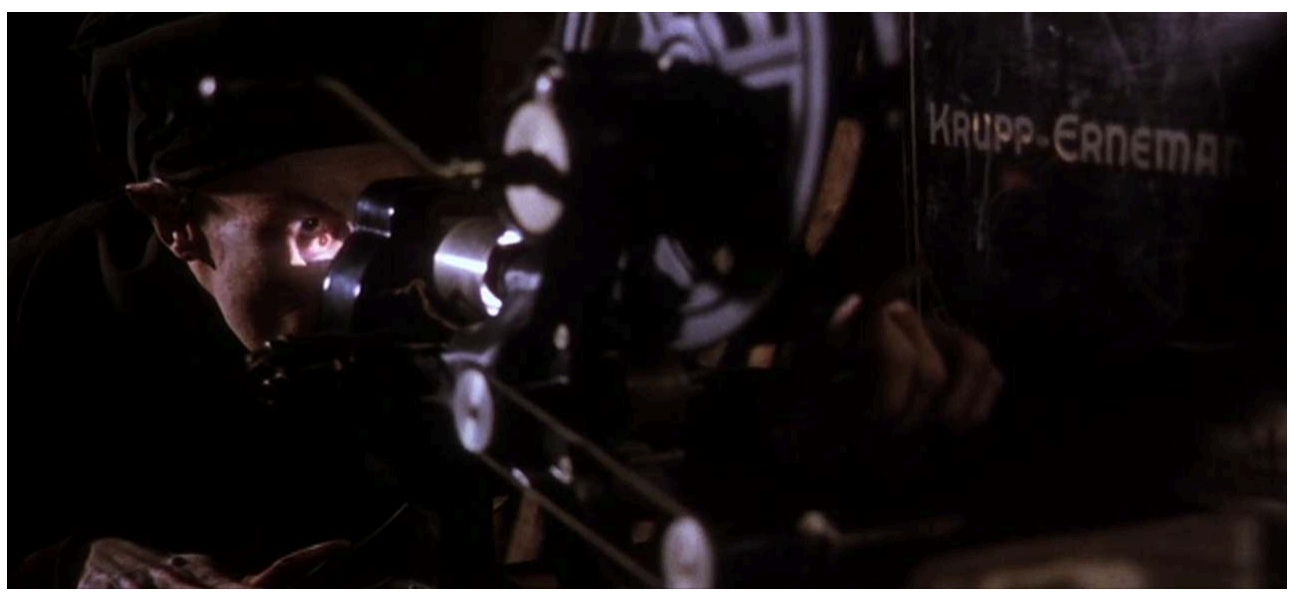

41 :04-Superimposition

14 This scene also represents the moment when the cinematic subject is offered a glimpse of his conflicting condition. The black-and-white of early cinema posits a dialectic of light and shadow, which encapsulates the relation between the diegetic subject on the one hand, and the technical, extra-diegetic dimension of cinema on the other, as Kyle Stine reminds us by quoting Jacques Aumont :

As Aumont notes, shadow and light share a dialectical relationship, with an important distinction: "Shadow and light need one another, but asymmetrically : there are sources of light, there are no sources of shade." If Aumont is right that the shadow in cinema reverses the situation and is the sine qua non of the light in terms of representation, then it follows that the projector lamp is in fact the shadow of cinema and, for this reason, is unseen. (Aumont 421)

This is all the more relevant for the era Shadow of The Vampire is set in. As the technical reality of early cinema was a much more integral part of the experience for its audiences than it is now, the emerging technology awed and sometimes terrified audiences through what Tom Gunning dubbed the technological uncanny (Stine 421). In the case of Nosferatu, the portrayal of Count Orlock calls into question Aumont's thesis by being equal parts light and shadow : if the vampire is seen in broad daylight in Wisborg, he is also metonymized by his shadow crawling up the stairs before his final crime. When the vampire stares directly into the projector, he connects with this dialectic, and thus with his impossible ontological status : his existence as a "source of light" and his inexistence as a mere shadow, only outlined by the light surrounding him.

16 A character confronting his fictional nature is hardly a first. Shadow of The Vampire employs its era, technicality and metafiction to accomplish this through the most fundamental elements of film : projected light and shadows. However, I will argue that before becoming a character on the verge of self-awareness, the vampire-juxtaposed with the surrounding context-is both an incarnation of the uncanny and an example of camp innocence. Freud defines the uncanny as the return of the repressed (the animistic) in the mind of the secular. Before the uncanny object can be approached discursively, processed and rationalized, a moment of "intellectual uncertainty" passes, materializing in a feeling akin to terror. This is precisely what happens to Gustav in his first encounter with the vampire. Murnau's description of the background of "Max 
Schreck" has been vague enough to provoke an uncanny feeling wherein Gustav is not quite sure of the nature of what he is facing (fig.14):

Figure 14

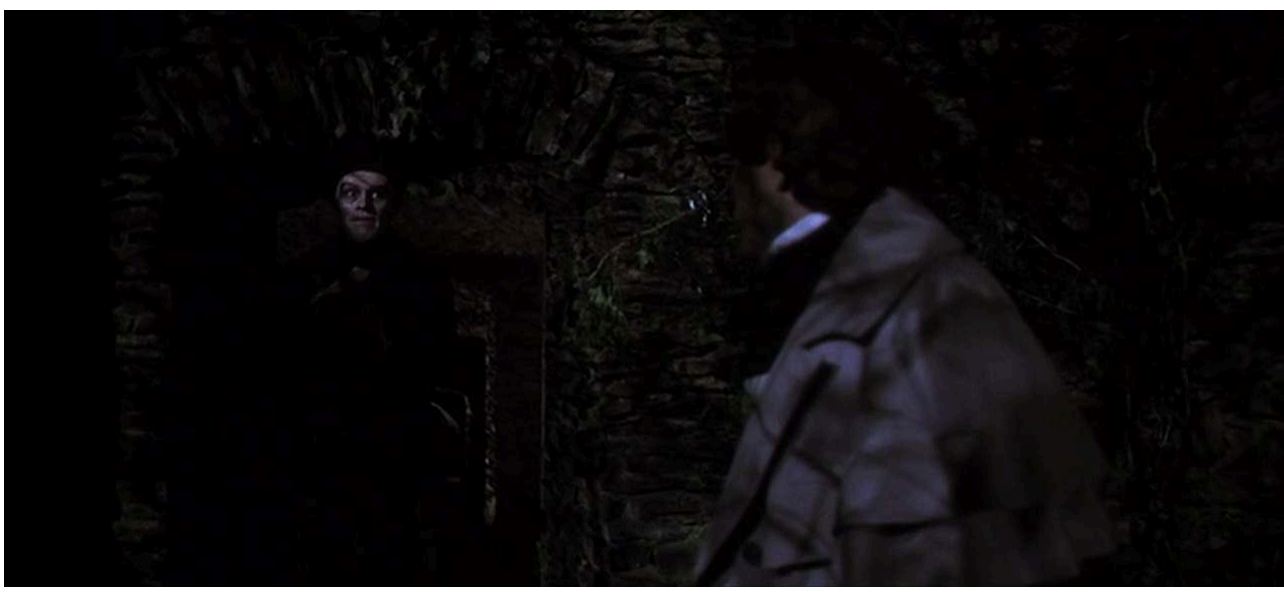

24 :05-An uncanny encounter.

17 "All one can say is that what is novel may well prove frightening and uncanny; some things that are novel are indeed frightening, but by no means all. Something must be added to the novel and the unfamiliar if it is to become uncanny" (Freud 125). In this case, what is added is the context of fiction-making and the "horizon of expectations" outlined by Murnau. However, as Freud specifies, the uncanny is a fleeting feeling, and from that point on cannot be maintained. Just as the uncanny power of cinema has vanished in the few decades following its apparition, the vampire also loses this power to the viewer as his gothic mannerism clashes immediately with the befuddled attitude of the people around him. This is why, after the first apparition of the vampire, he becomes close to what Susan Sontag defined as camp, an earnest, exaggerated and exuberant representation of something else. The vampire in itself is not camp, but he becomes so when juxtaposed with his environment and context :

Camp sees everything in quotation marks. It's not a lamp, but a "lamp"; not a woman, but a "woman." To perceive Camp in objects and persons is to understand Being-as-Playing-a-Role. It is the farthest extension, in sensibility, of the metaphor of life as theater. (Sontag 280)

18 Since to the rest of the cast, as well as the viewer, the "vampire" is not allowed to shake off his quotation marks, the persistence of his flamboyant nature in a secular world makes him shift into camp territory, a creature of the night in broad daylight, with apparent makeup and rubber ears.

The ontological gap in which the vampire resides is displaced from questions of verisimilitude or credibility onto themes of innocence and perspective. Shadow of The Vampire aligns with the ethos behind Tzvetan Todorov's opinion on truth in literature ${ }^{4}$ and a plot which could adopt a slasher-film structure turns into a contemplative decay of the earnest subject under the gaze of the camera. This can be observed toward the end of the film when the vampire, realizing he has been trapped in the room by Murnau, bares his teeth and threatens the crew. While he growls, "I can drink your blood" (1:23:48), Fritz Arno Wagner (Cary Elwes), the assistant camera operator, begins cranking the camera, granting absolutely no credit to the threats of the aging vampire. Following the reverse shot, the vampire continues his threats and the camera 
can still be heard rolling in the background. At his most terrifying, the vampire is merely good for an outtake, which makes the supposedly monstrous character the most innocent in the film. As Sontag points out, innocence is a crucial quality of camp : "Camp rests on innocence. That means Camp discloses innocence, but also, when it can, corrupts it. Objects, being objects, don't change when they are singled out by the Camp vision." (Sontag 283) In other words, the innocence of the vampire resides in his absolute lack of self-consciousness-with the make-up scene and the projector scene as signifiers of his struggle with this lack. The dialogue makes it clear that this camp quality is acknowledged by the rest of the cast (though the term is not used of course) : "Albin, please! The man is an artist. Ask him some vampire questions" [50:01]. These differences in access to self-consciousness suggest that in Shadow of The Vampire, the roles of monster and victim are reversed.

"A theatrical audience gives me life while this thing merely takes it from me" [08:58]) This line, in the first scene of the film by Greta Schröder (Catherine McCormack), foregrounds Shadow of the Vampire's awareness regarding the vampiric qualities of the camera. This is accomplished at the hand of Murnau whom the plot subtly and progressively constructs as a killer. The explicit impetus behind Murnau's actions is his flimsy, yet ostentatious obsession with realism. After Schröder has completed his first shot, Murnau exclaims, "Thank God, an end to this artifice," as a lengthy track-in reveals the plywood set (fig.15). Murnau then exits the set precipitously and the next scene finds him in what could be a cabaret or a brothel receiving a laudanum injection. This scene is notable because it may be the film's most expressionistic while remaining in the main continuity. The garish colors and Dutch angles contrast sharply with the more subdued style of the rest of the film and the music further confers to the scene a dreamlike quality as it ends on an abstract shot of the stage seen through a prism or diamond which fragments the bodies of the dancing couples (fig.16). The sequence betrays Murnau's expressionistic subjectivity, as the scene's aesthetics cast doubt over his pretensions to realism and objectivity. As we will see, this is a foreshadowing of his murderous intent.

Figure 15

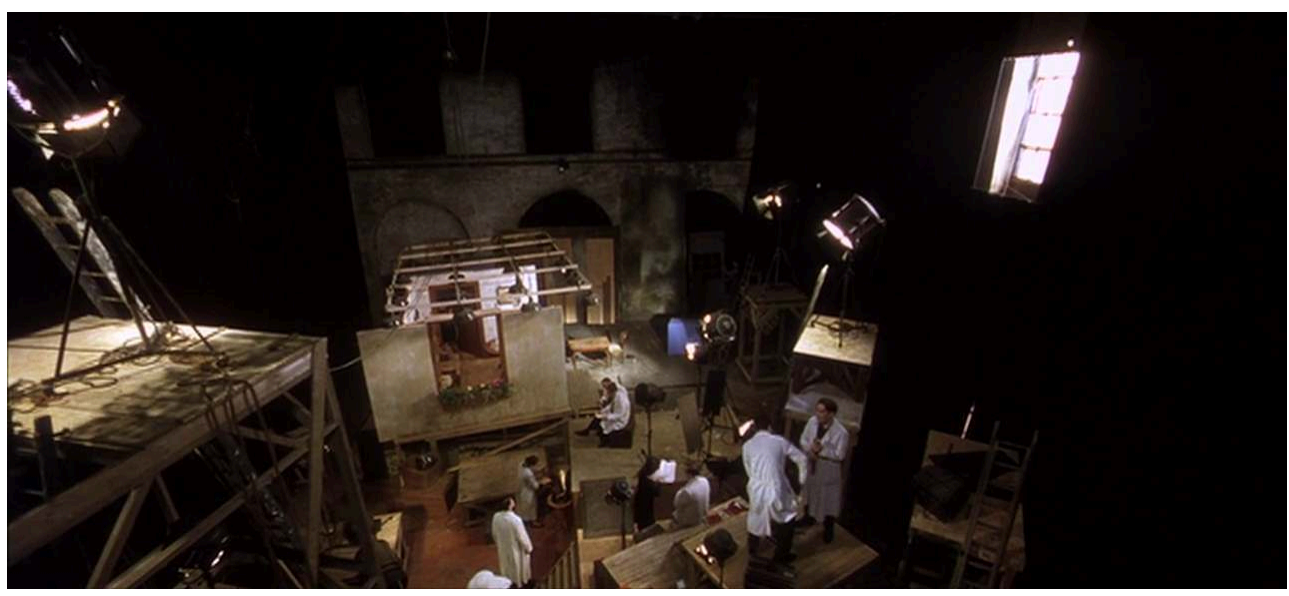

$08: 08$ - "An end to this artifice"-Crane shot tracking in on the plywood set 
Figure 16

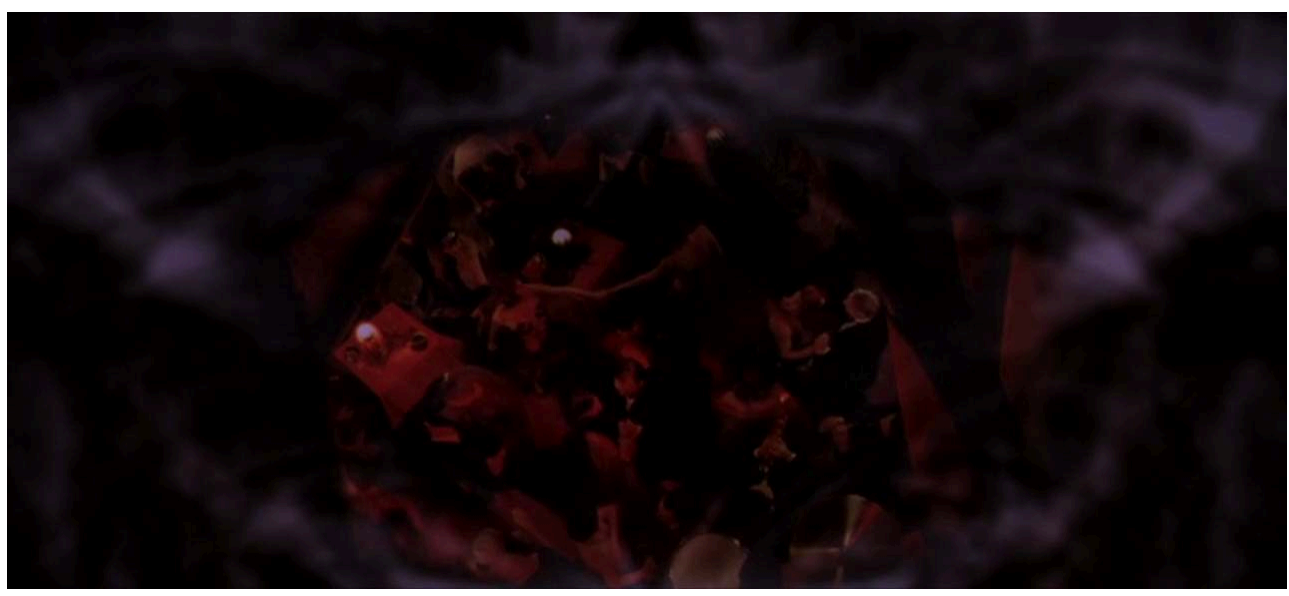

10 :54-Murnau's subjectivity

21 Later, when the crew objects to his choice of using the villagers of Wismar as extras, he objects, "They don't need to act, they need to be" [17:05], only to immediately burst out when one of them wanders in the frame: "A native has wandered into my frame" [20 : 34]. The authenticity Murnau wants to capture rapidly reveals itself to be a subjective fabrication, the underlying theme of his villainous arc. To that effect, the goggles worn by the director, on top of making him look like a mad scientist, are the symbol of his overpowering subjectivity, creating and reigning over a diegesis only he-and very optionally his crew-have access to. Anyone stepping in his frame must conform to his subjective construction of reality. This plot construction displays overt and covert forms of self-awareness, as defined by Hutcheon :

Overtly narcissistic texts reveal their self-awareness in explicit thematizations or allegorizations of their diegetic or linguistic identity within the texts themselves. In the covert form, this process is internalized, actualized; such a text is selfreflective but not necessarily self-conscious. (Hutcheon, 1981, p. 7)

The internalized self-awareness means the movie does follow the arc of a killer; however, it slowly appears that the killer we are focusing on is Murnau, not the vampire. In the final confrontation with the vampire, the use of color and black-andwhite suggests that Murnau can no longer differentiate between the two diegeses: Murnau has not stopped filming while the vampire executes the rest of the crew and after the massacre is over; the vampire locks eyes with the POV of the secondary diegesis, which at this point has become, for all intents and purposes, Murnau's subjective POV, his gaze having become indistinguishable from his camera's. What had been suggested as a proximity between the two POVs is revealed to be a terrifying fusion: as Murnau takes off his goggles (fig.17), the reverse shot of the vampire is edited in eyeline match and remains in black and white (fig.18). Murnau sees in black and white because he is the camera. This final reveal recontextualizes his directing ethos throughout the film. "Frankly, Count, I find this composition unworkable," says Murnau after having captured footage of actual murders at the hands of an actual vampire [85:03]. This line is an extension of the "native" line from earlier on, it suggests that, to Murnau, the interstitial text unfolding in front of the lens is a Kierkegaardian ethical sphere, the relation of a subject (the vampire) to law (cinema) : the events happening in front of the camera, no matter how truthful, are still subject to the director's approval of their value to his representation of them. In this scene, a 
debate is going on about what can be real in the context of cinema. Nothing is real to the director unless it has been processed through the discursive filter of cinematic grammar which, in turn, posits cinema as a totalitarian praxis which pretends to dictate what is while flattening what it sets out to capture under a narrow and overpowering subjectivity.

Figure 17

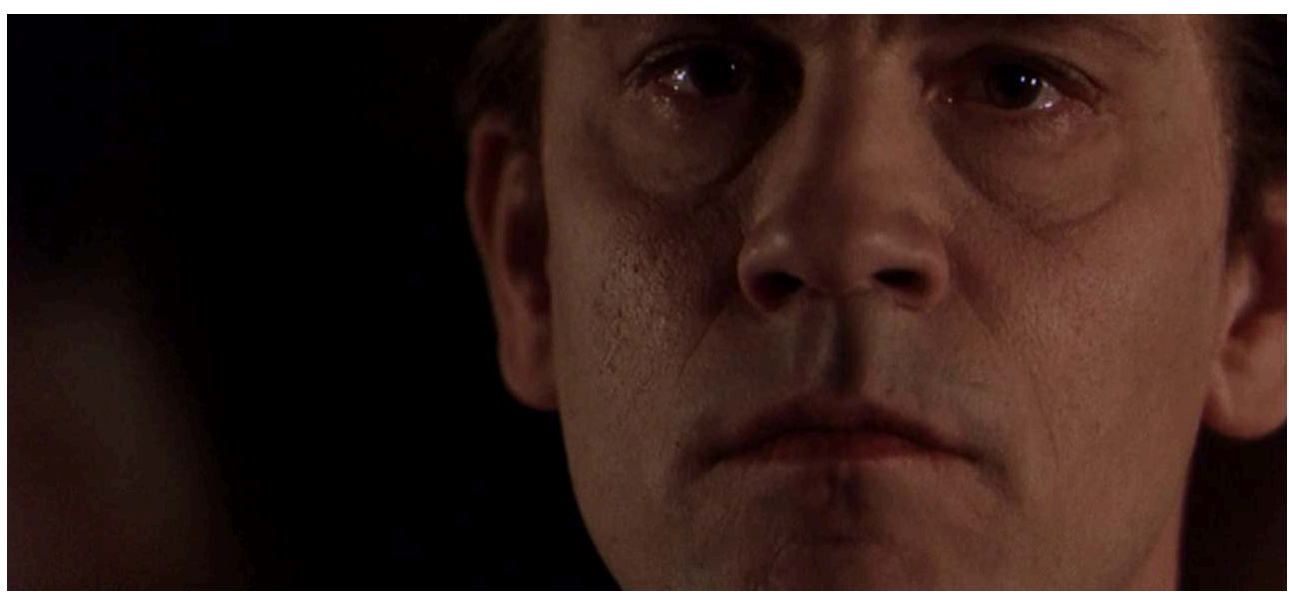

$1: 25: 14$

Figure 18

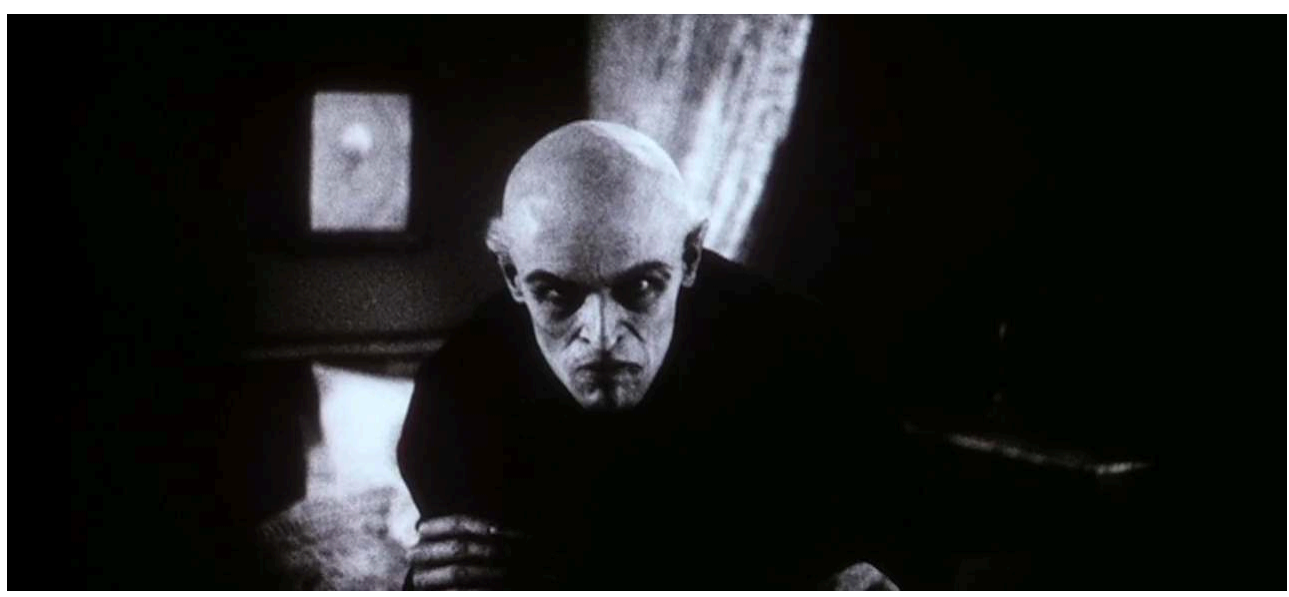

$1: 25: 16$

23 This praxis aligns with the relation between master and student outlined by Rancière. To establish the supremacy of representation over truth, ${ }^{5}$ Murnau teaches the vampire and the villagers how to be and, in so doing, applies the "endless verification of inequality" :

The primary knowledge that the master owns is the 'knowledge of ignorance.' It is the presupposition of a radical break between two forms of intelligence. This is also the primary knowledge that he transmits to the student: the knowledge that he must have things explained to him in order to understand, the knowledge that he cannot understand on his own. It is the knowledge of incapacity. In this way, progressive instruction is the endless verification of its starting point : inequality. That endless verification of inequality is what Jacotot calls the process of stultification (Rancière 275) 
In this instance, it appears clear that the metadiegetic space of filmmaking in Shadow of The Vampire is akin to the Debordian space of spectacle in Rancière's reading:

The Debordian critique of the spectacle still rests on the Feuerbachian thinking of representation as an alienation of the self: The human being tears its human essence away from itself by framing a celestial world to which the real human world is submitted. In the same way, the essence of human activity is distanced, alienated from us in the exteriority of the spectacle (Rancière 278)

A hierarchy is thus set up between the reality of human experience and its representation. Under the tyranny of the filmmaker, subjects are disposable; they are even expected to be destroyed in order to establish the supremacy of a nascent mode of representation. In the introduction to her essay on the intermedial incorporation in Nosferatu, Barbara Laner argues that Murnau's film is an act of vampirism exacted by cinema on preceding art forms, albeit a victimless one.

With the analogy of film as the vampire that feeds on the essences of the other arts [...] we can assume the positive energy film gains from the "life essences" of the other arts without the necessary death or destruction of its "victims." On the contrary, the vampire as a hybrid and cannibalistic figure stands for film as a genuine intermedial art form that absorbs and incorporates the aesthetics of the other arts to develop its own specificity. (Laner, p. 30)

Nosferatu's painterly influences having been largely documented, ${ }^{6}$ and if hindsight confirms that art has not ended with the apparition of cinema, it should appear obvious that Shadow of The Vampire seeks to vindicate the fears of literary critics of the time who "saw film as a rival to literature and attacked film adaptations of literary themes and works [...] arguing that film is devouring literary culture." (Laner, 29) In Mehrige's film, the representation of this process leaves a trail of bodies in its wake. Shadow of The Vampire depicts the Gesamtkunstwerk ${ }^{7}$ of cinema not as a furthering or synthesis of art, but as a tyrannical means to shock classical art forms into extinction. Indeed, it would seem that the entire impetus behind Shadow of The Vampire is to negate the idea of art history as a peaceful process, rather framing it as a battle for supremacy. This idea is clearly expressed when the vampire is trapped and killed by Murnau who exposes him to daylight. The vampire not only dies, but burns the actual film stock with him (fig.19). At this point, we can observe the diegeses coalescing into a single point, like a needle piercing through several layers of film stock. The diegetic spaces are superimposed; the vampire dies in a room in Shadow of The Vampire, Nosferatu and in its fictional recreation at the same time. The act of killing in all these texts is a foundation, a sacrifice ushering in a new artistic era with new modes of representation, killing the literary monster ${ }^{8}$ by dragging him under the scorching gaze of the camera. The death is also the culmination of the identity quest I have mentioned earlier. The telos of Shadow of The Vampire (i.e, the death of the vampire in the source material) is realized when the vampire meets his fate, in other words, finds himself:

Literature-and the novel in particular-seemed to many in the sixties and seventies, if not today, to have been playing with its own destruction. But has it not, rather, proved to be, as Barthes claimed, more like "cette héroïne racinienne qui meurt de se connaître mais vit de se chercher" ? (Hutcheon, 1981, p. 15)

Following Hutcheon's idea, the vampire dies because he has found himself, realizing the inevitable telos of Shadow of The Vampire in a vivid moment of dramatic irony. The very last line of the film, "Thank you, I think we have it," resonates as a declaration of ownership of film over literature, its subject and forms of representation are declared 
outdated by the mere existence of cinema. The camera has absorbed them all and retracts its fangs.

Figure 19

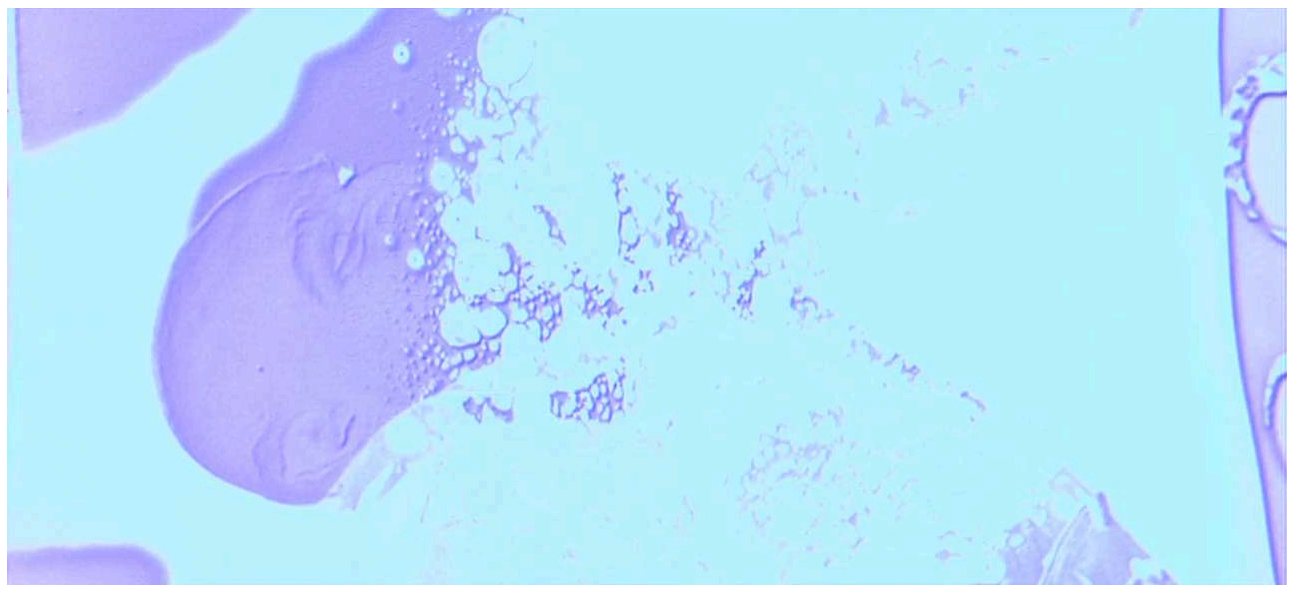

$1: 28: 02-$ Celluloid death

If Jacques Derrida talked about cinema as "The art of allowing ghosts to come back," Shadow of the Vampire makes a case for metacinema as a cruel follow-up to this process. The early-cinema myth of celluloid immortality is scrutinized under a stark light, tearing apart the characters it resurrects and subjecting them to a second death. By exploring the space between two texts, Merhige's metafiction opens a field of ethics, prescient in our age of industrialized nostalgia: should ghosts and monsters be ceaselessly unearthed and made to perform in an era when self-consciousness and irony have come to define large swaths of the discourse around popular culture? Although it is hard to perceive the film as prescriptive in this matter, its methods may serve to bring awareness of what is lost or altered when triumphalist art forms peruse at will from cinema's canon. Indeed, if Shadow of the Vampire stands on its own as an insightful reflection on the dreads of the evolution of art and representation, it also calls for perspective on the relation of contemporary film industry to horror and remakes. Cinema's uncanny moment has passed and its creatures, plucked at will from its back catalogue, may have lost their power to frighten. Just like Count Orlock in Wisborg, they are dangling in broad daylight. Metafiction reminds us of the dimension of art's power that is inherent to a medium. At the cost of suspending immersion, it allows a look at the ropes and involves the viewer into considering form and medium critically and diachronically. Perhaps Shadow of the Vampire can serve as a cautionary piece towards a more forward-thinking critical approach to horror and help rescue the genre from systemic staleness. Cinema may be immortal, but immortality can be tragically boring. 


\section{BIBLIOGRAPHY}

Andrew, Dudley. "Time for Epic Cinema in an Age of Speed." Cinema Journal ; Austin, Tex., Etc., vol. 55, no. 2, Winter 2016, pp. 135-146,157.

Atkinson, Michael. “Vampire Variations." Film Comment, no. 6, 2000, p. 27.

Auerbach, Nina. Our Vampires, Ourselves. New edition, University of Chicago Press, 1997.

Benjamin, Walter. "L'œuuvre d'art à l'époque de sa reproductibilité technique (dernière version de 1939).” in Euvres III. Paris : Gallimard, 2000 [1931], pp. 269-316.

Cerisuello, Marc. Hollywood à l'écran : Les métafilms américains. Paris : Presses de la Sorbonne Nouvelle, 2000.

Christie, Deborah G. "Through a Text Darkly : The Shape of the Fantastic in the Shadow of the Vampire." Dissertation Abstracts International, Section A : The Humanities and Social Sciences, vol. 65, no. 12, June 2005.

Elsaesser, Thomas. "Six Degrees of Nosferatu." Sight and Sound, vol. 11, no. 2, Feb. 2001, pp. 12-15. Genette, Gérard. Discours du récit. Points, 2007.

---. Figures III. SEUIL, Seuil, 1972.

Hutcheon, Linda. A Poetics of Postmodernism : History, Theory, Fiction. 1 edition, Routledge, 1988.

---. Narcissistic Narrative : The Metafictional Paradox. Wilfrid Laurier University Press, 2013.

Laner, Barbara. "The Vampiric Film : Intermedial Incorporation in 'Nosferatu, a Symphony of Horror." Post Script - Essays in Film and the Humanities ; Commerce, Tex., vol. 32, no. 1, Fall 2012, pp. 28-38.

Ranciere, Jacques. “The Emancipated Spectator.” ArtForum, vol. 45, Mar. 2007.

Sontag, Susan. Against Interpretation: And Other Essays. 1st edition, Picador, 2001.

Stine, Kyle. "Repressed Light : Cinema, Technics, and the Uncanny." Discourse ; Detroit, vol. 38, no. 3, Fall 2016, pp. 414-440,457.

Todorov, Tzvetan. Introduction à la littérature fantastique. Points, 2015.

\section{NOTES}

1. I am here using Marc Cerisuello's definition of a metafilm as a film that represents the industry and the act of filmmaking (pp. 92-93).

2. To avoid confusion and align with the narrative of Merhige's film, this article will refer to Willem Dafoe's character as 'the vampire'.

3. Mentions of Nosferatu as being recreated in Shadow will bear an asterisk to differentiate it from Murnau's film.

4. Literature is not a discourse that can or must be false...it is a discourse that, precisely, cannot be subjected to the test of truth; it is neither true nor false, to raise this question has no meaning: this is what defines its very status as "fiction". (Todorov, quoted in Hutcheon, 1988, p.109)

5. "If it's not in frame, it doesn't exist" (1:25:21). 
6. See Laner, Barbara. "The Vampiric Film: Intermedial Incorporation in 'Nosferatu, a Symphony of Horror." Post Script - Essays in Film and the Humanities; Commerce, Tex., vol. 32, no. 1, Fall 2012, pp. 28-38.

7. Total work of art incorporating many art forms.

8. Earlier in the film, Murnau confesses that it was Bram Stoker's novel that set him on his search for the real vampire.

9. McMullen, Ken. Ghost Dance. 1984.

\section{ABSTRACTS}

This article outlines the consequences and conditions of emergence of a meta-narrative in Shadow of the Vampire (E. Elias Mehrige, 2000), a film which invents an alternate version of the shooting of F.W Murnau's Nosferatu (1922). By positing Mehrige's film as a primary film and Nosferatu as a secondary film, I bring into focus an interstitial third text by fully considering the film-being-filmed and opening up the textual and formal devices of metafiction to demonstrate their overpowering influence upon its subjects in an attempt to inscribe these findings in a larger ethics of metafiction. This article interprets the relation between fiction and subject in Shadow of the Vampire as a struggle between artistic supremacy and existential survival. The analysis of the historiographical dimension of the film leads to interrogate the enduring uncanny power of cinema and open up larger questions about the historicity of images and their survival through time.

Cet article met en lumière les conséquences et les conditions d'émergence d'un méta-récit dans L'Ombre du Vampire d'E. Elias Mehrige, film uchronique mettant en scène le tournage de Nosferatu (1922) de F.W Murnau. En considérant le film de Mehrige comme film primaire et Nosferatu comme film secondaire, cet article met en exergue le troisième texte interstitiel que constitue le film-étant-filmé tout en analysant les procédés textuels et formels de la métafiction, afin de démontrer son influence dominatrice sur ses sujets et d'inscrire ces conclusions dans le champ plus général d'une éthique de la métafiction. Cet article interprète la relation entre fiction et sujet dans L'Ombre du Vampire comme une lutte entre suprématie artistique et survie existentielle. En tenant compte de la dimension historiographique du film, il s'agira de questionner la capacité du cinéma à conserver son pouvoir d'étrangeté et d'interroger de manière plus large la diachronicité des images et leur survie sur la durée.

\section{INDEX}

Keywords: American cinema, German cinema, Expressionism, horror, fantastic, metafiction, metacinema, Nosferatu, Shadow of the Vampire

Mots-clés: cinéma américain, cinéma allemand, expressionisme, horreur, fantastique, métafiction, métacinéma, Nosferatu, L'Ombre du vampire 


\section{AUTHORS}

JULIAN CARADEC

Étudiant Master 2 Recherche, Études Anglophones

Université Toulouse 2 Jean Jaurès

julian.caradec@gmail.com 